\title{
LOGISTIC REGRESSION TO ESTIMATE THE WELFARE OF BROILER BREEDERS IN RELATION TO ENVIRONMENTAL AND BEHAVIORAL VARIABLES
}

\author{
DANILO F. PEREIRA ${ }^{1}$, SANDRA C. DE OLIVEIRA ${ }^{2}$, NÁRIMA L. J. PENHA ${ }^{3}$
}

\begin{abstract}
The increasing demand of consumer markets for the welfare of birds in poultry house has motivated many scientific researches to monitor and classify the welfare according to the production environment. Given the complexity between the birds and the environment of the aviary, the correct interpretation of the conduct becomes an important way to estimate the welfare of these birds. This study obtained multiple logistic regression models with capacity of estimating the welfare of broiler breeders in relation to the environment of the aviaries and behaviors expressed by the birds. In the experiment, were observed several behaviors expressed by breeders housed in a climatic chamber under controlled temperatures and three different ammonia concentrations from the air monitored daily. From the analysis of the data it was obtained two logistic regression models, of which the first model uses a value of ammonia concentration measured by unit and the second model uses a binary value to classify the ammonia concentration that is assigned by a person through his olfactory perception. The analysis showed that both models classified the broiler breeder's welfare successfully.
\end{abstract}

KEYWORDS: poultry production, animal welfare, statistical model, animal precision.

\section{REGRESSÃO LOGÍSTICA PARA ESTIMATIVA DO BEM-ESTAR DE MATRIZES PESADAS EM FUNÇÃO DE VARIÁVEIS COMPORTAMENTAIS E AMBIENTAIS}

RESUMO: As crescentes demandas e exigências dos mercados consumidores pelo bem-estar das aves nos aviários têm motivado diversas pesquisas científicas a monitorar e a classificar o bem-estar em função do ambiente de criação. Diante da complexidade com que as aves interagem com o ambiente do aviário, a correta interpretação dos comportamentos torna-se uma importante maneira para estimar o bem-estar dessas aves. Este trabalho criou modelos de regressão logística múltipla capazes de estimar o bem-estar de matrizes pesadas em função do ambiente do aviário e dos comportamentos expressos pelas aves. No experimento, foram observados diversos comportamentos expressos por matrizes pesadas alojadas em câmara climática sob três temperaturas controladas e diferentes concentrações de amônia do ar monitoradas diariamente. A partir da análise dos dados, foram obtidos dois modelos de regressão logística, dos quais, o primeiro modelo utiliza um valor de concentração de amônia medida por equipamento, e o segundo modelo utiliza um valor binário para classificar a concentração de amônia, que é atribuída por uma pessoa através da sua percepção olfativa. As análises dos modelos mostraram que ambos classificaram satisfatoriamente o bem-estar.

PALAVRAS-CHAVE: avicultura de corte, bem-estar animal, modelo estatístico, zootecnia de precisão.

\section{INTRODUCTION}

The world has produced about 20 billion of broiler breeders, however on suspicion of mistreatment or inadequate rearing conditions for the welfare of these birds. The European Union has been a pioneer in setting standards for the welfare in the intensive rearing of animals. Therefore

\footnotetext{
${ }^{1}$ Eng $^{\mathrm{o}}$ Agrícola, Professor Doutor, Câmpus Experimental de Tupã, Universidade Estadual Paulista - UNESP, Tupã - SP, Fone: (0XX14) 3404-4200, danilo@tupa.unesp.br.

${ }^{2}$ Estatística, Professora Doutora, Câmpus Experimental de Tupã, Universidade Estadual Paulista - UNESP, Tupã - SP.

${ }^{3}$ Administradora, Câmpus Experimental de Tupã, Universidade Estadual Paulista - UNESP, Tupã - SP.

Recebido pelo Conselho Editorial em: 29-6-2010
}

Aprovado pelo Conselho Editorial em: 14-12-2010 
the meat-exporting countries which consider the EU as an important import market (as is the case of Brazil) should worry about reaching these new production requirements (BROOM, 2010).

The welfare is associated with mortality, physiology, behavior and health, particularly with the legs health and the bird's ability for walking (BILGILI et al. 2009; NAAS et al. 2010; SOSSIDOU \& ELSON, 2009). Jones et al. (2005), Moura et al. (2006) and SPINU et al. (2003) argued that the welfare of birds is more strongly associated with the environment of the aviary than with other factors related to creating, for example density. Therefore the complexity with which animals respond physiologically to environment associated with genetic characteristics and interactions among animals of a group (BESS, 2006, ZIMMERMAN et al. 2006; WEEKS \& NICOL, 2006) does not allow parameters for creation that are simply established by standards, for example $30 \mathrm{~kg} \mathrm{~m}^{-2}$ for poultry (BROOM, 2010, JONES et al., 2005), because in each region there is a specific condition for creation, given the climate and the types of the shed (FURTADO et al. 2006; JÁCOME et al., 2007, SANTOS et al. 2005; VITORASSO \& PEREIRA, 2009).

GRAVES (1982) stated that behavior is a window of the body for the outside, enabling better estimate with precision the welfare of birds. OLSSON et al. (2005) and DIXON et al. (2008) found that the behavior of taking the dust bath is an important indicator of social welfare of the group, and this behavior is mainly affected by the bedding material (JONG et al., 2007). ZIMMERMAN et al. (2006) observed that different sizes of groups provide significant differences in the expressions of aggressive behavior. PEREIRA et al. (2005) found that at the time of offering food, broiler breeders increase the frequency of aggressive behavior when the air temperature decreases.

The production of broiler breeders is an important segment of the chain broiler and poultry breeders should provide the conditions for welfare to meet the new demands. PEREIRA et al. (2005) found that the behavior of drinking water, scratching, taking a dust bath and lying down are important indicators of welfare of broiler breeders.

Given the difficulty of measuring the welfare of birds, mainly based on pre-set external parameters such as air temperature, stocking density, group size, food restriction, photoperiodism among others, this study aimed to develop an appropriate statistical model to estimate the welfare of broiler breeders, from behavioral and environmental data, using multiple logistic regression analysis.

\section{MATERIAL AND METHODS}

\section{Record of experimental data}

The experiment was conducted for nine consecutive days, with three strains of broiler breeders at peak production (Coob 500, Ross 308 and Hybro-PG) and ages ranging from 26 to 32 weeks during July and August 2005 in climatic chamber located in AEC-UNICAMP.

Three boxes were built inside the climatic chamber and three groups with 10 broiler breeders and two males (one group for each strain) were housed at a density of 3.5 birds $\mathrm{m}^{-2}$, on a bed of wood shavings. The lighting program was 17 hours with light (provided by fluorescent lamps) and 7 hours with darkness.

These birds were submitted to three conditions of air temperature: $26.3{ }^{\circ} \mathrm{C}, 29{ }^{\circ} \mathrm{C}$ and $35{ }^{\circ} \mathrm{C}$ and were exposed each condition during three days. The relative humidity was monitored by thermhigrometers Hobo H8 Pro-maker's Onset ${ }^{\circledR}$ installed at the center of each box. The ammonia concentration gas was monitored once a day using reagents tubes and Acura pump made by Dräger ${ }^{\circledR}$ manufacturer.

The birds had their behaviors observed by video cameras installed in the ceiling of the climatic chamber. The videos, each lasting 15 minutes, were captured and recorded by a computer installed in the adjoining room of the climatic chamber. It was collected a sample in the morning period (8am-12pm) and other sample in the afternoon period (2pm-6pm). Subsequently, these 
videos were watched and the frequency of occurrence and the time duration of each behavior expressed by the birds were recorded.

The environmental variables, air temperature and ammonia concentration, were used to formulate the proposed model. The behavioral variables considered in this paper were: frequency of the behavior of opening the wings $(F O W)$, bristling the feathers $(F B F)$, drinking water $(F D W)$, scratching $(F S C)$, sitting $(F S I)$, going to the water fountain $(F W F)$ and cleaning the feathers $(F C F)$; in addition to the average times for the expression of drinking water (TDW), scratching (TSC), sitting (TSI), going to the water fountain $(T W F)$ and cleaning the feathers $(T C F)$.

\section{Multiple logistic regression model}

The multiple logistic regression model considers a set of $k$ independent variables, which can be numeric or not, to predict the likelihood of the response variable $Y$. This model is expressed as

$$
\mathrm{Y}=\beta_{0}+\beta_{1} \mathrm{x}_{1}+\beta_{2} \mathrm{x}_{2}+\ldots+\beta_{\mathrm{k}} \mathrm{x}_{\mathrm{k}}+\varepsilon
$$

In the particular case where the response is binary qualitative (or dummy) is considered a random variable $Y$ of the type Bernoulli and taken only two values: "one" for the occurrence of the event, with a probability (of success) $\pi$, or "zero" for the absence of the event with a probability (of failure) $1-\pi$.

By definition of expected value, the conditional mean for dichotomous data is given by $E(Y \mid \mathbf{X}=\mathbf{x})=\pi(\mathbf{x})$. So

$$
\mathrm{E}(\mathrm{Y} \mid \mathrm{X}=\mathrm{x})=\beta_{0}+\beta_{1} \mathrm{x}_{1}+\beta_{2} \mathrm{x}_{2}+\ldots+\beta_{\mathrm{k}} \mathrm{x}_{\mathrm{k}}=\pi(\mathrm{x})
$$

As $E(Y \mid \mathbf{X}=\mathbf{x})$ should be between zero and one, then

$$
\begin{aligned}
& 0 \leq \mathrm{E}(\mathrm{Y} \mid \mathrm{X}=\mathrm{x}) \leq 1 \\
& 0 \leq \beta_{0}+\beta_{1} \mathrm{x}_{1}+\beta_{2} \mathrm{x}_{2}+\ldots+\beta_{\mathrm{k}} \mathrm{x}_{\mathrm{k}} \leq 1
\end{aligned}
$$

Thus, when the response variable is binary qualitative, the error $\varepsilon=1-\pi(\mathbf{x})$ has no normal distribution and the variance is heterogeneous, because it can take one of the following values:

$$
\begin{aligned}
& Y=1 \Rightarrow \varepsilon=1-\pi(x) \text { with probability } \pi(\mathbf{x}) \\
& \mathrm{Y}=0 \Rightarrow \varepsilon=-\pi(\mathrm{x}) \text { with probability } 1-\pi(\mathbf{x})
\end{aligned}
$$

To ensure that the response $Y$ is expressed as a probability, it is necessary the use of a link function between $\pi(\mathbf{x})$ and the linear predictor $\beta_{0}+\beta_{1} x_{1}+\beta_{2} x_{2}+\ldots+\beta_{k} x_{k}$. In this work we used the logit link (logistic distribution) or the logit transformation of the probability $\pi(\mathbf{x})$, which satisfies

$$
\ln \left\{\frac{\pi(\mathrm{x})}{1-\pi(\mathrm{x})}\right\}=\beta_{0}+\beta_{1} \mathrm{x}_{1}+\beta_{2} \mathrm{x}_{2}+\ldots+\beta_{\mathrm{k}} \mathrm{x}_{\mathrm{k}} .
$$

Expressing the equation (5) in terms of linear predictor (CORRAR et al., 2009)

$$
\pi(x)=\frac{e^{\beta_{0}+\beta_{1} x_{1}+\beta_{2} x_{2}+\ldots+\beta_{k} x_{k}}}{1+e^{\beta_{0}+\beta_{1} x_{1}+\beta_{2} x_{2}+\ldots+\beta_{k} x_{k}}}
$$

Thus, the multiple logistic regression model can be summarized by $Y=E(Y \mid \mathbf{X}=\mathbf{x})+\varepsilon$, where $E(Y \mid X=x)=\pi(x)=\frac{e^{\beta_{0}+\beta_{1} x_{1}+\beta_{2} x_{2}+\ldots+\beta_{k} x_{k}}}{1+e^{\beta_{0}+\beta_{1} x_{1}+\beta_{2} x_{2}+\ldots+\beta_{k} x_{k}}}$. 
The term $\ln \left\{\frac{\pi(\mathbf{x})}{1-\pi(\mathbf{x})}\right\}$ in (5) is called the logit mean response, where the ratio $\frac{\pi(\mathbf{x})}{1-\pi(\mathbf{x})}$ is called chance (odds). Particularly if $x=x_{j}$, such that chance $_{(j)}=\frac{\pi\left(x_{j}\right)}{1-\pi\left(x_{j}\right)}$, and $x=x_{j}+1$, such that chance $_{(j+1)}=\frac{\pi\left(x_{j}+1\right)}{1-\pi\left(x_{j}+1\right)}$, then the probability of an event occur (if under the same conditions, this event does not happen) is called odds ratio $(O R)$ and is given by

$$
\mathrm{OR}_{\mathrm{j}}=\frac{\text { chance }_{(\mathrm{j}+1)}}{\text { chance }_{(\mathrm{j})}}=\mathrm{e}^{\beta_{\mathrm{j}}}, \mathrm{j}=1,2, \ldots, \mathrm{k}
$$

In linear regression the method used to estimate the unknown parameters is the least squares method. However, this method is not efficient when it comes to a binary response model because it offers no plausible estimates, i.e., it is easily possible to obtain a response below zero or above one. How these values have no meaning then the results are unsatisfactory. In this case, the method used to estimate those parameters was the maximum likelihood method.

The statistical analysis was performed using Microsoft Excel spreadsheets and the Minitab Statistical Software. This software obtains adjusted and optimized models for the multiple logistic regression method using an iterative algorithm for generating the estimates of parameters of interest.

To assess the welfare of the birds were considered the answers obtained by interviewing three experts who had worked directly in the management of broiler breeders. They gave their opinions about the welfare of broiler breeders when the videos (captured in the experiment) were presented to them. They classified the welfare according to four categories: very good and good (indicating welfare), bad and very bad (indicating discomfort).

Two logistic models were developed to estimate the welfare of broiler breeders. The first model requires that the value of the ammonia concentration $(A C)$ to be recorded by measuring equipment. The second model categorizes the variable ammonia concentration and the input must be zero (low concentration) or one (high concentration). This classification is given by the sensitivity of human olfaction, because it realizes a more intense odor of the ammonia concentration when this concentration reaches values above $18 \mathrm{ppm}$.

\section{RESULTS AND DISCUSSION}

The relative humidity was between 60 and $70 \%$, which are considered as the limits of the thermoneutral zone for LIN et al. (2006). The ammonia concentration was between 6 and 26 ppm during the experiment, and it was observed the higher concentrations in the environment of higher temperatures $\left(35^{\circ} \mathrm{C}\right)$. LIN et al. (2006) and JONES et al. (2005) stated that the control of the environment, mainly of the temperature, relative humidity, quality of air and the bed are crucial for the welfare of birds.

Given the low variation observed about the relative humidity, which was always within the range of thermoneutrality, it was expected that only the air temperature and the ammonia concentration to be considered significant in the statistical models obtained for estimating the welfare.

The logistic models obtained considering the monitoring of the ammonia concentration with equipment (8), and the monitoring of the ammonia concentration using olfactory perception (9) were:

$$
\hat{\pi}=\mathrm{P}(\mathrm{Y}=1)=\frac{\mathrm{e}^{12,753-0,504 \mathrm{DBT}-0,304 \mathrm{AC}+0,541 \mathrm{FSI}+0,283 \mathrm{FDW}}}{1+\mathrm{e}^{12,753-0,504 \mathrm{DBT}-0,304 \mathrm{AC}+0,541 \mathrm{FSI}+0,283 \mathrm{FDW}}}
$$




$$
\hat{\pi}=\mathrm{P}(\mathrm{Y}=1)=\frac{\mathrm{e}^{19,43-0,751 \mathrm{DBT}-5,124 \mathrm{AC}+0,512 \mathrm{FSI}+0,217 \mathrm{FDW}}}{1+\mathrm{e}^{19,43-0,751 \mathrm{DBT}-5,124 \mathrm{AC}+0,512 \mathrm{FSI}+0,217 \mathrm{FDW}}}
$$

where $\hat{\pi}$ : welfare, $D B T$ : dry bulb temperature $\left({ }^{\circ} \mathrm{C}\right), A C$ : ammonia concentration (ppm), FSI : frequency of sitting (dimensionless) and $F D W$ : frequency of drinking water (dimensionless).

Considering the environmental conditions for the experiment (air temperature ranged between $26.3{ }^{\circ} \mathrm{C}$ and $35^{\circ} \mathrm{C}$ in model (8)), the odds ratio for the ambient temperature indicates that in low temperatures (close to $26.3{ }^{\circ} \mathrm{C}$ ) the birds have $60 \%$ more chance of being in the welfare condition than in the environment with high temperatures (around $35^{\circ} \mathrm{C}$ ), ever since keeping the other variables constant $\left(O R_{D B T}=0.60\right)$.

When the frequency of drinking water increases an additional unit, the chance of the bird of being in the welfare condition increases about $33 \%\left(O R_{F D W}=1.33\right)$. The chance of the welfare when the bird manifests the behavior of sitting is almost twice the chance of the welfare when that bird did not practice the behavior $\left(O R_{F S I}=1.72\right)$. This result coincided with Brack \& Hopster (2006) who reported that sitting is a natural behavior in many species and highly beneficial to the welfare of birds.

In model (9), the values of odds ratio can be interpreted as: environments with low temperature provide $47 \%$ more chance of the birds of being in the welfare condition than in environments with high temperatures $\left(O R_{D B T}=0.47\right)$; the chance of the welfare when the bird manifests the behavior of sitting is almost twice the chance of the welfare when that bird did not practice the behavior $\left(O R_{F S I}=1.67\right)$; and the chance of the bird of being in the welfare condition increases about $24 \%$ when the frequency of drinking water increases an additional unit $\left(O R_{F D W}=\right.$ 1.24). MACARI \& FURLAN (2001) stated that the water temperature affects the behavior of drinking water and this temperature must be close to $20^{\circ} \mathrm{C}$. Temperatures above the recommended can reduce the frequency of the use of water fountains.

With regard to ammonia, the analysis shows that environments with low concentrations provide $1 \%$ more chance of the birds to be in the welfare condition $\left(O R_{A C}=0.01\right)$, but it is noteworthy that the coefficient related to this variable is quite significant $(-5.124)$, and it indicates that when the ammonia level is high, i.e., $X_{2}=1$, this factor will influence in a significant reduction of the likelihood of welfare, ever since keeping the other variables constant.

McKEEGAN et al. (2005) and WATHES et al. (2002) observed that when it was given the choice between two environments (with ammonia concentration of 0,25 or $45 \mathrm{ppm}$ ), the hens preferred the fresh air environment, and in this ambiance, they scratched, cleaned the feathers and rested more significantly than in other environments. The frequency of the expression of these behaviors in environments with lower concentrations of ammonia indicates that this gas affects the welfare of birds, according to the logistic models whose coefficients related to this variable $(A C)$ were always negative.

In the situation of conditions of high concentration $(A C>18 \mathrm{ppm})$, the model (9) shown that the coefficient multiplying the dummy variable $A C$ is about eight times larger than other coefficients multiplying the remaining independent variables, corroborating the findings of WATHES et al. (2002). These researchers observed that the limit of ammonia concentration in the air that causes aversion to birds is less than $25 \mathrm{ppm}$.

The values obtained from $p$-value referring to the tests of Pearson, Deviance and HosmerLemeshow ranged from 0.616 to 0.820 for model (8), and from 0.428 to 0.670 for model (9). As these values are higher than the set level of significance $(10 \%)$, the tests do not rejected the hypothesis of appropriate adjustments of both models to the data. 
TABLE 1. Results of $p$-value and goodness fit indexes for the logistic models of the equations (8) and (9).

\begin{tabular}{cccccc}
\hline $\begin{array}{c}\text { Logistic } \\
\text { models }\end{array}$ & Pearson & $\begin{array}{c}\text { Deviance e Hosmer- } \\
\text { Lemeshow }\end{array}$ & $\begin{array}{c}\text { Somers' } \\
\text { D }\end{array}$ & $\begin{array}{c}\text { Goodman-Kruskal } \\
\text { Gamma }\end{array}$ & $\begin{array}{c}\text { Kendall's } \\
\text { Tau-a }\end{array}$ \\
\hline Equation (8) & 0.616 & 0.820 & 0.800 & 0.800 & 0.800 \\
Equation (9) & 0.428 & 0.670 & 0.780 & 0.780 & 0.360 \\
\hline
\end{tabular}

The Somers'D Goodman-Kruskal Gamma and Kendall's Tau-a indexes verify the predictive ability of estimated models. In model (8), these indexes showed values close to 1 or $100 \%$, meaning that the model has good skill $(80 \%)$ to predict the likelihood of response for the welfare. In model (9), were observed Somers'D, Goodman-Kruskal Gamma and Kendall's Tau-a indexes equal to $0.78,0.78$ and 0.36 , respectively, showing that the predictive ability of estimated model is around $78 \%$ and also has a good ability to predict the chance for the welfare.

SPINU et al. (2003) observed that the broiler breeders expressed behaviors of different ways according to the creation period (summer or winter) because the conditions of air temperature ranged between 18 and $33{ }^{\circ} \mathrm{C}$ and 7 and $17{ }^{\circ} \mathrm{C}$, respectively. In cooler temperature conditions the birds sit and drank more water than in higher temperature conditions.

It is known that the temperature of comfort for the birds must be between 21 and $24{ }^{\circ} \mathrm{C}$. Since the temperature conditions applied in this study had varied from 26.3 to $35^{\circ} \mathrm{C}$, it was expected that the higher the temperature value, the lower the welfare of birds. This perception was confirmed by the negative sign of the coefficient which multiplies the air temperature in the models (8) and (9).

The effects of behaviors observed in the welfare condition of the broiler breeders in the logistic models also corroborated with the observations of SPINU et al. (2003), because when the behaviors of sitting $(F S I)$ and of drinking water $(F D W)$ occur more frequently, they will contribute positively to the welfare (positive coefficients).

Consumer demand by production systems which ensure the welfare of animals tends to grow (SOSSIDOU \& ELSON, 2009) and production systems that provide insufficient welfare condition will be unsustainable over time (BROOM, 2010). Thus, statistical and mathematical models and computer algorithms to monitor and estimate the welfare conditions of animals in production are essential to ensuring markets for Brazilian poultry farming in the future.

The logistic models obtained in this study will contribute to the producer to estimate accurately the welfare of the birds, because models based on environmental conditions and on behavioral responses of birds and, according to GRAVES (1982), the birds express a set of sensations of the body with the environment, including environmental variables that were not being monitored.

The quantification of behavior could be obtained through direct observation by the producer, using the same methodology presented in this work. However, there are research papers that seek to identify and record the behaviors using computer vision systems and enable the automation of tracking birds (MIYAMOTO et al., 2008). The logistic models of this work associated to computer vision systems will provide the producer checking the welfare of the birds in real time.

It is expected that new logistic models can be developed by using other important behaviors in assessing the welfare of broiler breeders such as aggressiveness. DIXON et al. (2008) noted that the behavior of feather pecking of severe way is associated to motivational frustrations about scratching, and not about the dustbath, as reported by SHIELDS et al. (2004), because the morphology of feather pecking is closer to foraging, unlike the morphology of taking a dustbath and of cleaning the feathers. 


\section{CONCLUSION}

In this paper were obtained two logistic models to estimate the welfare of broiler breeders through stochastic methods and these models proved equally satisfactory estimates according to the adjust tests.

\section{ACKNOWLEDGEMENTS}

The authors thank the Fundação de Amparo à Pesquisa do Estado de São Paulo - FAPESP for the scientific initiation scholarship.

\section{REFERENCES}

BESSEI, W. Welfare of broilers: a review. World's Poultry Science Journal, New Zealand, v.62, 2006.

BILGILI, S.F.; HESS, J.B.; BLAKE, J.P.; MACKLIN, K.S.; SAENMAHAYAK, B.; SIBLEY, J.L. Influence of bedding material on footpad dermatitis in broiler chickens. The Journal of Applied Poultry Research, North Carolina, v.18, n.3, p.583-589, 2009.

BRACKE, M.B.M.; HOPSTER, H. Assessing the importance of natural behavior for animal welfare. Journal of Agricultural \& Environmental Ethics, Dordrecht, v.19, p.77-89, 2006.

BROOM, D.M. Animal Welfare: An Aspect of Care, Sustainability, and Food Quality Required by the Public. Journal of Veterinary Medical Education, Toronto, v.37, n.1, p.83-88, 2010.

CORRAR, L.J.; PAULO, E.; DIAS FILHO, J.M. Análise multivariada para os Cursos de Administração, Ciências Contábeis e Economia. Atlas: São Paulo, 2009.

DIXON, L.M.; DUNCAN, I.J.H.; MASON, G. What's in a peck? Using fixed action pattern morphology to identify the motivational basis of abnormal feather-pecking behavior. Animal Behaviour, Lethbridge, v.76, p.1.035-1.042, 2008.

FURTADO, D.A.; DANTAS, R.T.; NASCIMENTO, J.W.B.; SANTOS, J.T., COSTA, F.G.P. Effect of different environment conditioning systems on the productive performance of chickens Revista Brasileira de Engenharia Agrícola e Ambiental, Campina Grande, v.10, n.2, p.484-489, 2006.

GRAVES, H. B. Behavioral responses of poultry (chickens) to management systems. In:

Proceedings of the Symposium of Management of Food Producing Animals. West Lafayiette: Purdue University, 1982. v 2, p.122-138.

JÁCOME, I.M.T.D.; FURTADO, D.A.; LEAL, A.F.; SILVA, J.H.V.; MOURA, J.F.P. Evaluation of thermal comfort indexes for laying-hen houses in the Northeast of Brazil. Revista Brasileira de Engenharia Agrícola e Ambiental, Campina Grande, v.11, n.5, p.527-531, 2007.

JONES, T.A.; DONNELLY, C.A.; DAWKINS, M.S. Environmental and management factors affecting the welfare of chickens on commercial farms in the United Kingdom and Denmark stocked at five densities. Poultry Science, Stanford, v.84, p.115-165, 2005.

JONG, I.C.; WOLTHUIS-FILLERUP, M.; van REENEN, C.G. Strength of preference for dustbathing and foraging substrates in laying hens. Applied Animal Behaviour Science, Linköping, v.104, p.24-36, 2007.

LIN, H.; JIAO, H.C.; BUYSE, J.; DECUYPERE, E. Strategies for preventing heat stress in poultry. World's Poultry Science Journal, Cambridge, v.62, p.71-85, 2006.

MACARI, M.; FURLAN, R.L. Ambiência na produção de aves em clima tropical. In: SILVA, I.J.O. (Ed.). Ambiência na produção de aves em clima tropical. Jaboticabal: SBEA, 2001. p.31-87. 
McKEEGAN, D.E.F.; SMITH, F.S.; DEMMERS, T.G.M.; WATHES, C.M.; JONES, R.B. Behavioral correlates of olfactory and trigeminal gaseous stimulation in chickens, Gallus domesticus. Physiology \& Behavior, Cincinnati, v.84, p.761-768, mar. 2005.

MIYAMOTO, B.C.; PEREIRA, D.F.; MAGALHÃES, M.M. Visão computacional aplicada à identificação de comportamentos de matrizes pesadas. In: SEMINÁRIO DE CONSTRUÇÕES RURAIS E AMBIÊNCIA APLICADAS À PRODUÇÃO ANIMAL, 1., 2008, Tupã. p. 1-10.

MOURA, D.J.; NÄÄS, I.A.; PEREIRA, D.F.; SILVA, R.B.T.R.; CAMARGO, G.A. Animal welfare concepts and strategy for poultry production: a review. Brazilian Journal of Poultry Science, Campinas, São Paulo, v.8, n.3, p.137-147, 2006.

NÄÄS, I.A.; PAZ, I.C.L.A.; BARACHO, M.S.; MENEZES, A.G.; LIMA, K.A.O.L.; BUENO, L.G.F.; MOLO, M.M.; CARVALHO, V.C.; ALMEIDA, I.C.L.; SOUZA, A.L. Assessing locomotion deficiency in broiler chicken. Scientia Agrícola, Piracicaba, v.67, n.2, p.129-135, 2010.

OLSSON, I.A.; KEELING, L.J. Why in earth? Dustbathing behaviour in jungle and domestic fowl reviewed from Tibergian and animal welfare perspective. Applied Animal Behaviour Science, Linköping, v.93, n.3-4, p.259-282, 2005.

PEREIRA, D.F.; NÄÄS, I.A.; ROMANINI, C.E.B.; SALGADO, D.D.; PEREIRA, G.O.T. Welfare pointers in function of behavior reactions of broiler breeders. Engenharia Agrícola, Jaboticabal, v.25, n.2, p.308-314, 2005.

SANTOS, P.A.; YANAGI JÚNIOR, T.; TEIXEIRA, V.H.; FERREIRA, L. Thermal environment inside models of poultry housings in reduced scale with natural and artificial ventilated roofs. Engenharia Agrícola, Jaboticabal, v.25, n.3, p.575-584, 2005.

SHIELDS, S.J.; GARNER, J.P.; MENCH, J.A. Dustbathing by broiler chickens: a comparison of preference for four different substrates. Applied Animal Behaviour Science, Linköping, v.87, p.6982, 2004.

SOSSIDOU, E.N.; ELSON, H.A. Hens' welfare to egg quality: a European perspective. World's Poultry Science Journal, Beekbergen, v.65, n.4, p.709-718, 2009.

SPINU, M.; BENVENESTE, S.; DEGEN, A.A. Effect of density and season on stress and behaviour in broiler breder hens. British Poultry Science, Roslin, v.44, n.2, 2003. p.170-174.

VITORASSO, G.; PEREIRA, D.F. Comparative analysis of the environment of poultry sheds with different systems of acclimatization. Revista Brasileira de Engenharia Agrícola e Ambiental, Campina Grande, v.13, n.6, p.788-794, 2009.

WATHES, C.M.; JONES, J.B.; KRISTENSEN, H.H.; JONES, E.K.M.; WEBSTER, A.J.F. Aversion of pigs and domestic fowl to atmospheric ammonia. American Society of Agricultural Enginners, St. Joseph, v.45, n.5, p.1.605-1.610, 2002.

WEEKS, C.A.; NICOL, C.J. Behavioural needs, priorities and preferences of laying hens. World's Poultry Science Journal, Cambridge, v.62, p.296-307, 2006.

ZIMMERMAN, P.H.; LINDBERG, A.C.; POPE, S.J.; GLEN, E.; BOLHUIS, J.E.; NICOL, C.J. The effect of stocking density, flock size and modified management on laying hen behaviour and welfare in a non-cage system. Applied Animal Behaviour Science, Linköping, v.101, p.111-124. 2006. 